\title{
SUPERQUADRATIC FUNCTIONS IN INFORMATION THEORY
}

\author{
JosiPA BARIĆ, ĐILDA PEČARIĆ AND JosiP PEČARIĆ
}

Abstract. Using Jensen's inequality and the converse Jensen's inequality for superquadratic functions we obtain new estimates for Shannon's entropy of the random variable $X$ and derive new lower and upper bounds for the Shannon entropy in the terms of the Zipf and ZipfMandelbrot's law.

Mathematics subject classification (2010): 94A15, 94A17, 26D15, 26 A51. law.

Keywords and phrases: Superquadratic function, Jensen's inequality, Shannon entropy, Zipf-Mandelbrot's

\section{REFERENCES}

[1] S. Abramovich, J. Barić, J. PeČarić, Fejer and Hermite-Hadamard type inequalities for superquadratic functions, J. Math. Anal. Appl., 344, (2008), 1048-1056.

[2] S. ABramovich, J. BARIĆ, J. PeČARIĆ, A variant of Jessen's inequality of Mercer's type for superquadratic functions, JIPAM, 9 (3), (2008), article 62, 13 pp.

[3] S. Abramovich, J. BARIĆ, J. PeČArić, Superquadracity, Bohr's inequality and deviation from a mean value, AJMAA, 7 (1), (2010), 1-9.

[4] S. Abramovich, G. Jameson and G. Sinnamon, Refining Jensen's inequality, Bull. Math. Soc. Sc. Math. Roumanie 47 (95), (2004), 3-14.

[5] S. Abramovich, G. Jameson, G. Sinnamon, Inequalities for averages of convex and superquadratic functions, J. Inequal. Pure and Appl. Math., 5 (4), (2004), Article 91.

[6] S. BAnić, J. PeČARIĆ, S. VARošAnEC, Superquadratic functions and refinements of some classical inequalities, J. Korean Math. Soc. 45 (2), (2008), 513-525.

[7] M. E. J. Newman, Power Laws, Pareto Distributions and Zipf's law, Contemporary Physics, (2005) 46: 323-351.

[8] Marcelo A. Montemurro, A generalization of the Zipf-Mandelbrot law in linguistics, Nonextensive Entropy, interdisciplinary applications, Oxford University Press, (2004).

[9] B. MANDELBRot, The fractal structure of nature, Freeman: New York, 1983.

[10] B. MANDELBRot, An informational theory of the statistical structure of languange, In Jackson, W. editor, Communication Theory, New Yord. Academic Press, (1953), 486-502.

[11] M. Matić, C. E. PeArCe, J. PeČArić, Shannon's and related inequalities in information theory, Survey on Classical Inequalities, Springer, Dordrecht, (2000), 127-164.

[12] D. S. Mitrinović, J. E. PeČArić, A. M. FinK, Classical and New Inequalities in Analysis, Kluwer Academic Publishers, Dordrecht/Boston/London, (1993). 